\title{
Japon Eğitim Sisteminde Çözüm Bekleyen Bir Sorun: “Zorbalık”
}

\author{
Levent Toksöz
}

Doğu Dilleri ve Edebiyatı Bölümü, Fen Edebiyat Fakültesi, Tekirdă̆ Namık Kemal Üniversitesi, Tekirdă̆, Türkiye

Sorumlu Yazar: Levent Toksöz, ltoksoz@nku.edu.tr

Makale Türü: Derleme Makalesi

Kaynak Gösterimi: Toksöz, L. (2021). Japon Eğitim Sisteminde çözüm bekleyen bir sorun: “Zorbalık”. Eğitimde Kuram ve Uygulama, 17(Özel Say1 1), 31-46. doi: 10.17244/eku.873124

Etik Not: Araştırma ve yayın etiğine uyulmuştur. Bu çalışma, "Derleme Makalesi” olup ayrıca bir etik onay süreci işletilmemiştir.

\section{A problem awaiting solution in the Japanese Education System: "Bullying"}

\section{Levent Toksöz}

Department of Easter Languages and Literature, Faculty of Science and Literature, Namik Kemal University, Tekirdag, Turkey

Corresponding Author: Levent Toksöz, ltoksoz@nku.edu.tr

Article Type: Review Article

To Cite This Article: Toksöz, L. (2021). Japon Eğitim Sisteminde çözüm bekleyen bir sorun: “Zorbalık”. Ĕgitimde Kuram ve Uygulama, 17(Özel Sayı 1), 31-46. doi: 10.17244/eku.873124

Ethical Note: Research and publication ethics were followed. This study is "Review Article"; hence, no proceed an ethical clearance evaluation. 


\title{
Japon Eğitim Sisteminde Çözüm Bekleyen Bir Sorun: "Zorbalık”
}

\author{
Levent Toksöz \\ Doğu Dilleri ve Edebiyatı Bölümü, Fen Edebiyat Fakültesi, Namık Kemal Üniversitesi, Tekirdă̆, Türkiye \\ ORCID: https://orcid.org/0000-0003-2212-2976
}

\begin{tabular}{|c|c|}
\hline$\ddot{O} z$ & Makale Bilgisi \\
\hline 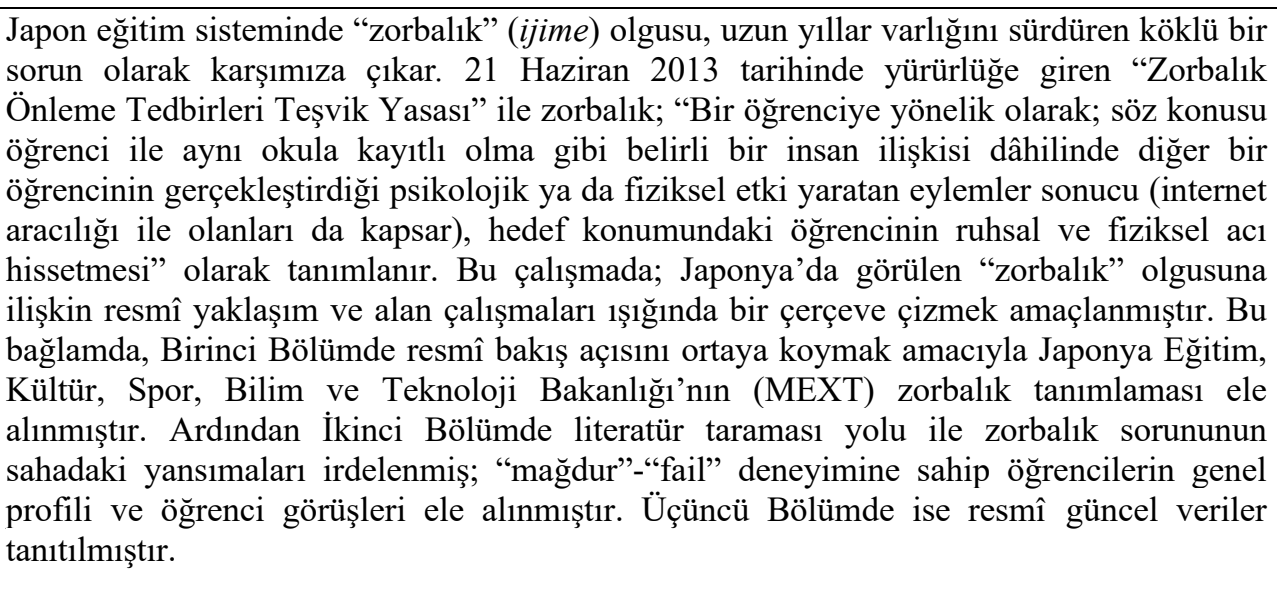 & $\begin{array}{l}\text { Anahtar kelimeler: Japon } \\
\text { eğitim sistemi, Mağdur - fail } \\
\text { profili, Öğrenci görüşleri, } \\
\text { Resmî politika, Zorbalık } \\
\text { Makale Geçmişi: } \\
\text { Geliş: } 2 \text { Şubat } 2021 \\
\text { Düzeltme: } 31 \text { Mart } 2021 \\
\text { Kabul: } 16 \text { Haziran } 2021 \\
\text { Makale Türü: Derleme } \\
\text { Makalesi }\end{array}$ \\
\hline
\end{tabular}

\section{A Problem Awaiting Solution in the Japanese Education System: "Bullying"}

\begin{abstract}
The phenomenon of 'bullying' (ijime) in the Japanese education system emerges as a deeprooted problem that has persisted for many years. In the "Act for the Promotion of Measures to Prevent Bullying" entered into force on June 21, 2013, bullying (including cyber bullying) is defined as an act inflicted on a child by another child having a certain degree of relationship with the bullied victim (for example, both attending the same school), which causes the target students either physical or psychological pain. In this study, it is aimed to form a frame in the light of the official approach and field surveys regarding the phenomenon of 'bullying' seen in Japan. In this context, in order to reveal the official perspective, the definition of 'bullying' by the Japanese Ministry of Education, Culture, Sports, Science and Technology (MEXT) is discussed in the first section. Then, in the second section, the reflections of the problem of bullying in the field are examined by means of literature review; the general profiles of students with the experience of 'victim' - 'perpetrator' - and their views are examined. In third section, official current data are introduced.
\end{abstract}

\section{Article Info}

Keywords: Japanese Education System, Victim - perpetrator profile, Student views, Official policy, Bullying

\section{Article History:}

Received: 2 February 2021

Revised: 31 March 2021

Accepted: 16 June 2021

Article Type: Review Article 


\section{Extended Summary}

The phenomenon of 'bullying' (ijime) in the Japanese education system emerges as a deep-rooted problem that has persisted for many years. In this study, it is aimed to form a frame in the light of the official approach and field surveys regarding the phenomenon of 'bullying' seen in Japan. In this context, in the first section, the definition of 'bullying' by the Japanese Ministry of Education, Culture, Sports, Science and Technology (MEXT) is discussed in order to reveal the official perspective. Then, in the second section, the reflections of the problem of bullying in the field are examined by means of literature review; the general profiles of students with the experience of 'victim' 'perpetrator'- and their views are examined. In third section, official current data are introduced.

MEXT goes through four changes in the definition of bullying in 1986, 1994, 2006 and 2013. Suicide cases, which caused public resentment in the years mentioned, had great effects on these changes. In the 'Act for the Promotion of Measures to Prevent Bullying' entered into force on June 21, 2013, bullying (including cyber bullying) is defined as an act inflicted on a child by another child having a certain degree of relationship with the bullied victim (for example, both attending the same school), which causes the victim either physical or psychological pain. The expressions such as 'unilateral', 'continuous', 'deep pain' used in descriptions of bullying before 2013 are not included in this definition. Changes, such as the establishment of a bullying prevention commission within each school, bear the traces of as many early detection and intervention strategies as possible.

When it comes to 'bullying' action; primarily, it comes to mind that the dominant student behaves inappropriately with the target student. On the other hand, many studies conducted in Japan show that the 'perpetrator' and 'victim' positions are not fixed; they reveal that students can experience both positions throughout their education life. Studies on 'victim' students show that students in this group generally exhibit cheerless, angry, reluctant, depressive, and anxious characteristics. On the other hand, concepts such as 'anger control', 'egoity', 'overcoming the stress' about students with bullying behaviour distinguish. It is seen that among the children who resort to bullying, there are also a considerable number of those who are subjected to maltreatment or excessive expectations at home, who experience stress at school, and who head for these behaviours as a signal of help.

When the views of Japanese students on the phenomenon of bullying are examined; it is seen that while finding bullying 'wrong', they can defend the view that 'there may be problems with the aggrieved party'. Especially at the secondary school level, the tendency to associate the source of the problem with the victim becomes much stronger in acts of bullying such as 'ignoring' and 'excluding from friendship'. On the other hand, among those who commit bullying, there are also those who, although they feel sorry for the victim, participate in the bullying out of fear of being excluded from the group (so that they do not become a victim).

According to the MEXT report, in 2018, the number of bullying cases increased by 31 percent compared to the previous year $(2018: 543,933 ; 2017: 417,378)$. The number of cases increasing every year in the last five years is interpreted as adopting a more sensitive approach to case detection, not worsening of the situation. The most common bullying situation at all levels appears as 'chilliness, taunting, swearing, threatening, scolding or bad words'. This theme is followed by 'light hitting, being beaten or kicked under the name of a game' in primary and secondary schools and 'slander or encountering unpleasant situations on the computer or mobile phone' in high schools. In the third place, 'being excluded by friends, ignored by the group' is observed at all levels.

The prominent points in this study, which aims to form a frame in the light of official data and literature review, can be evaluated under the headings of 'the reflection of the official perspective on the field' and 'the reason for bullying'.

With the law enacted in 2013, the new definition, which aims to record as many cases as possible with a victim-oriented approach, also causes some confusion in the field. Foremost among these is the subjective perception difference. A behavior that a student or parent defines as bullying may be considered as a joke by the other student or parent; responsible teacher may not see an action, which is defined as bullying by the victim, as a problem.

Although MEXT accepts these sounds rising from the field as understandable; it reminds that the majority of suicide cases due to bullying start with events deemed unimportant, and demands that teachers comply with the definition in the law. According to the Ministry, even if it is a one-time action, any event that causes physical or mental pain should be considered as a 'case' without distinction. It can be said that MEXT takes a decisive stance to spread the approach based on the definition in the law in order to eliminate the perception difference in the field.

On the other hand, strong traces of the 'collectivist' tendency are found at the root of the problem of bullying; 'collectivism', which is defined as the identification of one's own purpose with the common purpose of the group to which it belongs is esteemed in Japanese society. We come across studies that evaluated this problem in two ways in the 1980s, when bullying started to be discussed as a problem, as 'discrimination against those who do not adapt to a homogeneous collective atmosphere' and 'one's fear of being excluded from this homogeneous group alone'. Findings such as 'the problematic aspect of the other party', 'participation in action with fear of exclusion' seen in field studies on the justification of bullying of today's students indicate that the collectivist tendency in question is still valid. Planned and decisive steps taking into account the collectivist tendency in question are important in possible strategies to be followed towards the basis of the problem, such as 'tolerating personal difference'. 


\section{Giriș}

Japonya'nın II. Dünya Savaşı sonrası gösterdiği gelişim küresel anlamda dikkat çekici niteliktedir. Ülkenin 1980'li yıllarda üçüncü büyük ekonomik güce erişmesi, en az "Alman mucizesi" kadar yaygın olan "Japon mucizesi" söylencesini dünya gündemine sokar (Güvenç, 2002, s. 56). Bu model kapsamında ülkemizde de sıklıkla dile getirilen "Japonların çağdaşlaşırken kültür ve geleneklerinden vazgeçmediği" argümanı Türklerin Japonya algısında hâlen güçlü bir şekilde etkisini hissettirir (Toksöz, 2020).

Japon mucizesinin Türkiye'de ele alındığı görece erken yıllarda bu başarıyı "eğitim sistemi” ile ilişkilendiren çalışmalara rastlansa da (ör. Güçlüol, 1984); ilerleyen y1llarda Japon eğitim sistemindeki uygulamalara yönelik araştırmaların istenilen seviyeye ulaşmadığı görülür (Ekinci, 2010). Japon eğitim sistemini konu alan çalışmaların eğitim sistemindeki kurumsal yapı, fiziksel altyapı ve öğretim programı odaklı bir yaklaşım sergilediği ifade edilmektedir (Özşen, 2020).

Elbette ki, genel hatları ile Japon eğitim sitemini tanıtan, Türk eğitim sistemine entegre edilebilecek noktaları betimleyen, okul öncesi eğitim gibi belirli öğretim programına odaklanan çalışmalar alan yazın için değerlidir (ör. Ekinci, 2010; Liman, 2012; Baydilek-Başaran, 2015 vb.). Diğer yandan bu çalışmaların birçoğunda "ahlak eğitimine" özel bir atıf yapıldığı görülür. Örneğin; Ekinci (2010), Japon eğitim sisteminin başarısını "etkili değer ve ahlak eğitimi" ile ilişkilendirmekte; Liman (2012), söz konusu ahlak eğitimini "öz-kontrol”, "diğerleriyle yaşama ve iletişim", "yaşamın önemini anlama, doğaya ve çevreye saygı duyma", "eşitlik, adalet gibi toplum kurallarına saygı duyma" olarak dört ilkede aktarmaktadır. Japonya'da sınıf temizliği ve yemek dağıtımından öğrencilerin sorumlu olması ya da okula girişlerde terlik giyilmesi bu kapsamda vurgulanan örnekler arasındadır (Tekışık, 2006, aktaran Kıral \& Kıral, 2009). Kuşkusuz, Japon eğitim sisteminde ahlak eğitiminin yeri ve önemi yadsınamaz; fakat konuya tarafsız ve kapsamlı yaklaşabilmek için sınıflara terlik ile girilmesi örnek gösterilirken, sınıf arkadaşları tarafından terliklerine raptiye yerleştirilen ya da sıralarına incitici notlar bırakılan öğrencilerin varlığına da değinmek gerekir. Bu çalışmada, Japon eğitim sisteminde uzun yıllar köklü bir sorun olan "zorbalık" (ijime) olgusu ele alınacaktır.

Japonya Eğitim, Kültür, Spor, Bilim ve Teknoloji Bakanlığı (Monbukagakushō; metin içinde "MEXT”) resmî verilerine göre 2018 y1lında zorbalık vaka sayıs1; ilkokullarda 425.844, ortaokullarda 97.704, liselerde 177.709, özel destek okullarında 2.676, toplamda 543,933 olarak kayıtlara geçmiştir (Monbukagakushō, 2019a). Vaka sayısının bu denli yüksek olmasında, ilgili politika gereği nispeten tolere edilebilir durumların da vaka olarak kayıt altına alınmasının etkisi büyüktür. Fakat 2018 yılında; intihar başta olmak üzere yaşam, beden ya da maddi varlıkla ilişkili ciddi vaka sayısının 270'i bulması, durumun önemine işaret eder. İçişleri ve İletişim Bakanlığı İdari Değerlendirme Bürosunca hazırlanan bir raporda "zorbalı nedeniyle meydana gelen intihar gibi ciddi vakaların sonu alınamamaktadır." ifadesine yer verilir (Sōmushō gyōseihiyōkakyoku, 2018).

Zorbalık; Japon eğitim sisteminde can yakıcı bir sorun olarak varlığını sürdürmektedir. Bu çalışmanın amacı; Japonya'da "zorbalık"1 olgusuna ilişkin resmî veriler ve alan çalışmaları 1şı̆̆ında durum değerlendirmesi yapmak; soruna ilişkin bir çerçeve çizmektir. Bu bağlamda; Birinci Bölümde kavramsal açıdan zorbalık tanımının zaman içindeki değişimi ve resmî yaklaşım incelenecek; İkinci Bölümde literatür taraması yolu ile zorbalık olgusunun sahadaki yansımaları ele alınacak; Üçüncü Bölümde sahada yaşanan zorbalık vakaları güncel resmî veriler 1şı̆̆ında irdelenecektir. Çalışmada atıfta bulunulan tüm resmî rapor, yazı ve genelgeler MEXT'in web sayfasında açık arşiv olarak sunulmaktadır². Çalışma ile ülkemizdeki Japon eğitim sistemine ilişkin alan yazına katkı sunmak; "zorbalık" üzerine yapılacak araştırmalara "Japonya örneği” bağlamında kullanabilir veri sağlamak hedeflenmiştir.

\section{Kavramsal Açıdan Zorbalık Olgusu ve Resmî Yaklaşım}

\section{Zorbalık Tanımı ve Zaman İçindeki Değişimi}

MEXT; öğrencilerin ${ }^{3}$ problemli davranışları ve rehberlikte yaşanan sorunlara ilişkin düzenli olarak gerçekleştirdiği saha çalışmasında zorbalık tanımına ilişkin 1986, 1994, 2006 ve 2013 yıllarında dört kere değişikliğe gider (Monbukagakushō, 2019b). Anılan yıllardaki değişiklilerde, kamuoyunda geniş yankı bulan intihar vakalarının etkisi büyüktür (İtō, 1996; Kobayashi \& Miwa, 2013; Shimoda, 2014; Nakano, 2018 vd.) Aşağıda, zorbalık tanımlamalarında görülen değişikliler MEXT (2019b)'den yararlanarak irdelenecek; bu değişimlerin arkasında yer alan dönemsel özellikler ve intihar vakaları Nakano (2018, ss. 12-21)'nun çerçevesine bağlı kalınarak aktarılacaktır.

\footnotetext{
${ }^{1}$ Zorbalık olgusunun taraflarına ilişkin Türkçe literatürde "zorba" ve "kurban" terimi sıklıkla kullanılırken, Japonca literatürde kagaisha ("fail", "zarar veren kişi”) ve higaisha ("mağdur", "zarar gören kişi) terimleri tercih edilmektedir. Bu nedenle çalışmada "fail” ve "mağdur" terimleri kullanılacaktır.

${ }^{2}$ https://www.mext.go.jp/a menu/shotou/seitoshidou/1302904.htm

${ }^{3}$ Japonca resmî yazışmalarda kullanılan jidōseito ifadesi çalışmada "öğrenci” olarak aktarılacaktır. Anlam bakımından jidō ifadesi "küçük çocuk ve ilkokul öğrencileri” için, seito ifadesi ise "ortaokul ve lise öğrencileri” için kullanılır.
} 


\section{Birinci Zorbalık Tanımı (1986-1994)}

Zorbalık olgusu 1980'lere kadar Japon kamuoyunda yeterince bilinmemektedir. Söz konusu yıllarda konuya “okul içi şiddet” çerçevesinde yaklaşılmaktadır. 19 Nisan 1985'te Asahi Gazetesi'nin Emniyet Teşkilatı verilerine dayandırdığ 1 "Zorbalık Nedeniyle 7 İntihar" manşeti, zorbalık olgunun kamuoyundaki bilinirliğine katkı sağlar (Suzuki, 1995).

Konunun toplumda yankı uyandırması, ortaokul ikinci sınıf öğrencisi Nakano Fujimi'nin intiharı ve ölmeden önce yazdığı "Böyle devam ederse, cehennemi yaşamış olacağım" notunun medyaya yansımasıyla olur (21 Şubat 1986). Bu olayın ardından öğrenciler arasındaki sürtüşmeler zorbalık bağlamında değerlendirilmeye başlanır. MEXT'in 1986 yılı saha araştırmasında; "Bu araştırmada zorbalık; (1) kişinin kendisinden zayıf kişiye yönelik tek tarafl, (2) bedensel ve psikolojik saldırıda sürekli bulunması sonucu (3) karşı tarafin derin acı hissetmesi olarak tanımlanır. Okulun söz konusu gerçekliğe ilişskin (ilgili taraflar, zorbalık içeriği vb.) teyidi gereklidir. Olayın meydana geldiği yerin okul içi ya da dışı olması fark yaratmaz," ifadeleri kullanılır ${ }^{4}$ (Monbukagakushō, 2019b).

\section{İkinci Zorbalık Tanımı (1994-2006)}

Birleşmiş Milletler Genel Kurulu'nca 20 Kasım 1989 tarihinde benimsenen Çocuk Hakları Sözleşmesi'nin 22 Nisan 1994'te Japonya'da yürürlüğe girmesi, zorbalık olgusuna bakış1 etkiler. Öğrencileri korumakla yükümlü okul yönetiminin bu sorumluluğu yerine getirememesi hâlinde yasal sorumluluk altına girmesi doğal karşılanır. Bu döneme kadar okul yönetiminin soruşturma raporlarında zaman zaman kullandığı "mağdur tarafinda da sorun olduğu" ifadesi insan hakları çerçevesince yasaklanır (Takanori, 1999).

$\mathrm{Bu}$ dönemde Aichi şehrinde meydana gelen ortaokul ikinci sınıf öğrencisinin kendisini asarak intiharı Japon kamuoyunda gündem yaratır (27 Kasım 1994). Çocuğun, annesine ithafen yazdığı mektubunda uzun yıllar arkadaşlarınca harçlı̆ğının elinden alındığı ve bu eylemde bulunanların isimleri yazılıdır. Okul yönetimi, on bir öğrenciyi olayla ilişkili bulur; içlerinden dördünün ilkokul altıncı sınıftan itibaren eylemi gerçekleştirdiği sonucuna varır. $\mathrm{Bu}$ olayın ardından MEXT, 1994 yılındaki saha araştırmasında; "Bu araştırmada zorbalık; (1) kişinin kendisinden zaylf kişiye yönelik tek tarafl, (2) bedensel ve psikolojik saldırıda sürekli bulunması sonucu (3) karşı tarafin derin acı hissetmesi' olarak tanımlanır. Her bir eylemin zorbalık teșkil edip etmediği konusundaki karar yüzeysel ya da biçimsel olarak değil, zorbalı̆̆a uğrayan ögrencinin bakıs açısına dayanılarak verilecektir," ifadelerine yer verir (Monbukagakushō, 2019b). Böylece, zorbalık tanımlamasında değişikliğe gidilmezken, bu tarihten itibaren okul yönetiminin somut teyidi yerine mağdur öğrencinin bakış açısı esas alınmaya başlanır.

Aynı yıl "okul danışmanlık sistemi" (sukūru kaunserā) hayata geçer. Zorbalık vakalarındaki artış ve sorun çözümünü sadece okul yönetiminden beklemenin yaratacağı olumsuzluklar nedeniyle öğrenci, öğretmen ve velilere danışmanlık yapmaları için her okula uzman personel atanır (Ōtsuka, 2012). Haftada bir veya iki kez yarı zamanlı olarak istihdam edilen bu uzmanların görev tanımında; "öğrencilere danışmanlık ve bilgi paylaşımı", "veli ve öğretmenlere tavsiye ve yardım", "okul yönetiminin gerekli gördüğü diğer konularda tavsiye ve yardım" yer almaktadır (Sugihara, 2013).

\section{Üçüncü Zorbalık Tanımı (2006-2013)}

$\mathrm{Bu}$ dönemde medyada yer alan iki intihar vakası devlet okullarının zorbalığa yönelik tavrının kamuoyunca tekrar tartışılmasına neden olur. Hokkaidō'da gerçekleşen ilkokul altıncı sınıftaki bir kız öğrencinin intihar olayında okul yönetimi vakanın zorbalıktan kaynaklandığını kabul etmez (9 Eylül 2005). Fakat ailenin intihar mektubunu medya ile paylaşması sonucu yönetim özür dilemek zorunda kalır.

Fukōka'da meydana gelen ikinci olayda ise (15 Ekim 2006), ortaokul ikinci sınıf öğrencisini intihara sürükleyen olayda sorumlu öğretmenin uygun olmayan sözleri kamuoyunca eleştirilir. Bu vakaların ardından MEXT; 2006 yılındaki saha araştırmasında "Bu araştırmada bir eylemin zorbalık teşkil edip etmediğinin kararı yüzeysel ya da biçimsel olarak değil, zorbalığa uğrayan ögrencinin bakış açısına dayanılarak verilecektir. Zorbalık; bir öğrencinin belirli bir insan ilisskisi dâhilinde bulunduğu basska bir kișiden; psikolojik, fiziki saldırıya maruz kalma sonucunda ruhsal acı hissetmesi olarak tanımlanır," ifadelerine yer verir (Monbukagakushō, 2019b). Ayrıca ilk kez "vaka sayısı" yerine "tanımlanmış vaka sayısı" ifadesi kullanılarak "tanımlanamayan vaka" ihtimaline ilişkin ön kabul mesajı verilir.

\section{Dördüncü Zorbalık Tanımı (2013)}

Ōtsu şehrinde meydana gelen intihar olayında yakın arkadaşlarının sözlü ve fiilî şiddeti sonucu ortaokul ikinci sınıf öğrencisi hayatına son verir (11 Ekim 2011). Soruşturma raporunda okul yönetimi olayı "zorbalık" değil "kavga" olarak nitelendirirken intihar nedeni olarak aile içi sorunlara işaret eder. Olayın medyaya yansıması sonucu belediye başkanı talimatıyla ikinci bir soruşturma başlatılır; okul ve eğitim komisyonunun aileye yaptığı açıklamanın eksik ve gerçekle örtüşmediği anlaşılır.

\footnotetext{
${ }^{4}$ Numaralı ve altı çizili ifadeler MEXT (2019b)'e aittir.
} 
Bu olayın ardından MEXT, 2 Kasım 2012 tarihinde; suç eylemi içeren zorbalık davranışlarında erken dönemde polis ile istişarede bulunmayı zorunlu kılan bir yazı yayınlar (Monbukagakushō, 2012). Ardından 21 Haziran 2013 tarihinde, Zorbalık Önleme Tedbirleri Teşvik Yasası (Ijime bōshi taisaku suishinhō) yürürlüğe girer. MEXT bu tarihten sonraki saha araştırmalarında yasadaki zorbalık tanımını kullanır. Yasa ile "zorbalık" -günümüzde de geçerli olduğu hâliyle-; "Bir öğrenciye yönelik olarak; söz konusu ögrenci ile aynı okula kayıtlı olma gibi belirli bir insan ilişkisi ${ }^{5}$ dâhilinde diğer bir ögrrencinin gerçekleştirdiği psikolojik ya da fiziksel etki yaratan eylemler sonucu (internet aracıliğ ile olanları da kapsar), hedef konumundaki ögrencinin ruhsal ve fiziksel acı hissetmesi," olarak tanımlanır (Monbukagakushō, 2019b). Ayrıca, yasa ile her okul bünyesinde zorbalığı önlenmeye yönelik temel ilkelerin belirlenmesi (madde 13); birden fazla öğretim personeli ile psikolojik danışman ya da sosyal hizmetler görevlisinden oluşan bir kurul oluşturulması zorunlu kılınır (madde 22).

\section{Zorbalık Önleme Tedbirleri Teşvik Yasası Sonrası Uygulamalar}

Yürürlüğe giren Zorbalık Önleme Tedbirleri Teşvik Yasası sonrası; uygulamaya yönelik bir dizi çalışma yürütüldüğünü görmekteyiz. 11 Nisan 2014 tarihinde tüm okullara gönderilen resmî yazıda, ailelere yönelik hazırlanan zorbalığı fark etme amaçlı kontrol çizelgesinden okulların da yararlanması istenir (Monbukagakushō, 2014a). Tablo 1'de söz konusu kontrol çizelgesinde yer alan maddeler belirtilmektedir.

Tablo 1. Zorbalı̆̆g Fark Etme Amaçlı Kontrol Çizelgesi

\begin{tabular}{|c|c|}
\hline \multicolumn{2}{|r|}{ - Zorbalığa uğruyor olabilir mi? } \\
\hline Sabah & $\begin{array}{l}\square \text { Sabah kalkmıyor. Yataktan kolay kolay çıkmak istemiyor. } \\
\square \text { Sabah olduğunda vücudunu iyi hissetmediğini söylüyor ve okula gitmek istemiyor. } \\
\square \text { Geç kalma ve okuldan erken çıkmaları çoğaldı. } \\
\square \text { İştahsız ya da yemeğini sessizce yemeye başladı. }\end{array}$ \\
\hline Okul Dönüşü & $\begin{array}{l}\square \text { Cep telefonu ya da mesaj sesinden ürküyor. } \\
\square \text { Ders çalışmaz oldu. Konsantrasyonu yok. } \\
\square \text { Evden para alıyor ya da ihtiyacından fazlasını istiyor. } \\
\square \text { Oyunlarda gülünüyor; alay ediliyor ya da emir veriliyor. } \\
\square \text { Yakın arkadaşları artık eğlenmek için eve gelmiyor; o da eğlenmeye gitmiyor. }\end{array}$ \\
\hline Akşam & $\begin{array}{l}\square \text { Yüz ifadesi asık ve aile sohbetlerine katılımı azaldı. } \\
\square \text { Küçük şeylere sinirleniyor veya bir şeylere vuruyor. } \\
\square \text { Konuşmalarında okul ya da arkadaş konuları azaldı. } \\
\square \text { Odasına kapandığı zamanlar arttı. } \\
\square \text { Bilgisayarına ya da akıllı telefonuna aşırı tepki gösteriyor. } \\
\square \text { Sebebini açıkça söylemediği morluklar ya da yara izleri oluyor. }\end{array}$ \\
\hline Gece & $\begin{array}{l}\square \text { Uykuya dalmakta zorlanıyor veya devamlı olarak geceleri uyuyamadığı günler söz konusu. } \\
\square \text { Okulda kullandığı eşyalar kaybolmuş veya bozulmuş oluyor. } \\
\square \text { Kitap ya da defterlerine taciz edici çizimler yapılmış veya yırtılmış. } \\
\square \text { Giysileri kirlenmiş veya yırtılmış. }\end{array}$ \\
\hline \multicolumn{2}{|r|}{ Zorbalıkta bulunuyor olabilir mi? } \\
\hline & $\begin{array}{l}\square \text { İfadeleri kaba bir hâl aldı. Söylenenleri dinlemiyor. İnsanlarla alay ediyor. } \\
\square \text { Satın aldığınızı hatırlamadığınız eşyaları var. } \\
\square \text { Verdiğiniz paradan fazlasına sahip. Harçlığıyla satın alamayacağı şeylere sahip. }\end{array}$ \\
\hline
\end{tabular}

Aynı yılının Kasım ayında, zorbalıkla etkin mücadelenin sahada yaygınlaşması amacıyla olumlu örnek teşkil eden okulların yer aldığı "vaka örnekleri" yayınlanır (Monbukagakushō, 2014b). Fakat ilerleyen zamanda, ülke genelinde arzulanan standart yaklaşımda sorun yaşandığı tespit edilir. 2 Kasım 2016 tarihinde, MEXT bünyesinde faaliyet gösteren "Zorbalık Önleme Tedbirleri Komisyonu" yasanın uygulama durumuna ilişkin tartışmalı noktaları özetlerken vaka sayısının en düşük ve en yüksek olduğu bölgelerde oluşan otuz katlık farkı "sahadaki algı farklılığının göstergesi”" olarak yorumlar (Ijime bōshitaisaku kyōgikai, 2016). Bunun üzerine 2017 yılında MEXT tarafından "ciddi zorbalık durumu" soruşturmalarına ilişkin yeni bir kılavuz yayımlanır (Monbukagakushō, 2017a). Söz konusu kılavuzda "şüphe" durumunun soruşturma başlatılması için yeterli olduğu; mağdur veya veli beyanına "ciddi durum oluşmuş" ön kabulü ile yaklaşılması gerektiği ifade edilir. Ardından; aynı yıl, zorbalık önlemine ilişkin temel ilkelerin revize edildiği bir genelge yayınlanır (Monbukagakushō, 2017b). Genelge ile "ruhsal ve fiziksel acı" ifadesinin dar

\footnotetext{
${ }^{5}$ Tanımda kullanılan "belirli bir insan ilişkisi” ve "fiziksel etki” ifadelerinin sahada doğru yorumlaması için MEXT, 2017 yılında açıklık getirir. Buna göre "belirli bir insan ilişkisi”" ifadesi; okul içi ve dışı ayrımı yapılmaksızın aynı okul, sınıf veya kulüp etkinliğinin yanı sıra dershane, spor kulübü vb. yerlerdeki tüm kişisel ilişkileri kapsar. Diğer yandan "fiziksel etki” ifadesi sadece vücut bütünlüğünü değil; para ya da eşyanın zorla alınması ya da saklanması, hoşlanılmayan bir durumun zorla yaptırılması gibi durumları da içerir (Monbukagakushō, 2017b, s.5).
} 
çerçevede yorumlanmaması gerektiği; öğrencinin zorbalığa uğrasa da bunu inkâr edebileceğinin altı çizilir. Zorbalık tanımlamasının öğretmen deneyimine göre değil yasaya göre yapılması istenen genelgede, tolere edilebilir nitelikteki olayların da okul bünyesindeki ilgili kurul ile paylaşılması ve vaka olarak kayıtlara geçilmesi istenir (Monbukagakushō, 2017b, ss. 4-6).

2018 yılı Mart ayında İçişleri ve İletişim Bakanlığı İdari Değerlendirme Bürosu tarafından hazırlanan "Zorbalık önlem tedbirlerinin teşvikine ilişkin araştırma sonuç raporu" MEXT ve Adalet Bakanlığına tavsiyeler içerir. $\mathrm{Bu}$ bağlamda, ciddi vakalara ilişkin okul ve yerel yönetimlerce hazırlanmış altmışaltı soruşturma raporunun analiz edildiği bölüm, önemli tespitler içerir. Buna göre, ciddi vakaların büyük bölümünün "soğuk davranma ve alay etme" gibi sıradan sayılan eylemlerle başladığı; 9 intihar vakasının 5'inde çevredeki tanıkların maktulün "ölmek istiyorum", benzeri imalarını olay öncesi fark ettiği sonucuna ulaşılır. Okul yönetimi ve yerel yönetimlerce hazırlanmış söz konusu altmışaltı vakaya ilişkin soruşturma raporunda görülen eksikler Tablo 2' de ifade edildiği gibi "zorbalık anlayışı", "okul içi bilgi paylaşımı", "kurumsal yaklaşım”, "durum sonrası yaklaşım”, "anket kullanımı" ve "öğretmen eğitimi”" başlıklarında özetlenebilir (Sōmushō gyōseihiyōkakyoku, 2018, s. 207-247).

Tablo 2. Ciddi Vakalara İlişkin 66 Soruşturma Dosyasında Görülen Eksiklikler

\begin{tabular}{|c|c|}
\hline Sinıflandirma & Sorunlu Örnekler \\
\hline $\begin{array}{l}\text { Zorbalık algılayışı } \\
27 \text { vaka (yüzde 56) }\end{array}$ & $\begin{array}{l}\text { Okul personelinin, } 2006 \text { y1lı öncesi kullanılan "sürekli”, “tek taraflı” ve “derin” ifadelerinin güncel zorbalık } \\
\text { tanımlamasında hâlâ geçerli olduğunu sanmasi; durumu zorbalık kapsamında değerlendirmemesi. }\end{array}$ \\
\hline $\begin{array}{l}\text { Okul içi bilgi } \\
\text { paylaşımı } \\
40 \text { vaka (yüzde } 61 \text { ) }\end{array}$ & $\begin{array}{l}\text { Öğrencinin sınıf öğretmenine durumu danışmasına rağmen, öğretmenin zorbalık sorunu kapsamında okul içinde gerekli } \\
\text { bilgi paylaşımında bulunmaması. }\end{array}$ \\
\hline $\begin{array}{l}\text { Kurumsal yaklaşım } \\
42 \text { vaka (yüzde } 64 \text { ) }\end{array}$ & $\begin{array}{l}\text { Mağdur ile yapılacak görüşme gibi konularda durumun ele alınış şeklinin okul tarafından paylaşılmaması; tüm } \\
\text { sorumluluğun öğretmene bırakılması. }\end{array}$ \\
\hline $\begin{array}{l}\text { Durum sonrası } \\
\text { yaklaşım } \\
23 \text { vaka (yüzde } 35)\end{array}$ & $\begin{array}{l}\text { Okulun sorumlu personelince yasanın amaç ve içeriğinin tam olarak anlaşılmaması; meydana gelen ciddi durumun } \\
\text { ardından yerel yönetim merciine gecikerek bildirimde bulunulması. }\end{array}$ \\
\hline $\begin{array}{l}\text { Anket kullanımı } \\
18 \text { vaka (yüzde } 27)\end{array}$ & Yapılan ankette "zorbalık var" cevabının alındığı durumlarda izlenecek somut düzenlemenin olmaması. \\
\hline $\begin{array}{l}\text { Öğretmen eğitimi } \\
30 \text { vaka (yüzde } 46 \text { ) }\end{array}$ & orbalık sorununa odaklanan öğretmenlere rehberlik kabiliyetini geliştirmeye yönelik eğitim verilmemesi. \\
\hline
\end{tabular}

İçişleri ve İletişim Bakanlığı İdari Değerlendirme Bürosunun bu raporunun ardından MEXT, 2018 y1lı Eylül ayında soruşturma raporlarına dayalı toplu vaka örnekleri yayınlar (Monbukagakushō, 2018). Daha önce yayınlanan (Monbukagakushō, 2014), toplu vaka örneklerinden farklı olarak sadece olumlu örneklere değil; uygunsuzluk tespit edilen örneklere de yer verilir. Örneğin, ciddi vakalar bölümünde yer alan toplam üç vakanın ikisi yetersiz ve eksik soruşturmaya (vaka 45,46); biri ise uygun soruşturmaya (vaka 47) örnek olarak sunulur (Monbukagakushō, 2018, ss. 119-122, Tablo 3).

Tablo 3. Ciddi Vakalara İlişkin 3 Olay ve Bakanlık Yorumu (özet)

Vaka 45: Ayrıntılı soruşturma yapmadan "Zorbalık yok" hükmü verilmesi

• Ortaokul üçüncü sınıftaki kız öğrenci A, intihar sonucu ertesi gün evinde ölü bulunur. Aile; okul üniformasının cebinde "kokuyorsun" yazılı bir nota; kızlarının günlügünde ise "zorbalığa uğramak istemiyorum," ifadesine rastlar. Aile, bu kanıtları okul yönetimine sunarak A'nın sınıftaki kız öğrencilerce zorbalığa uğradığını iddia eder.

•• Okulun anket araştırması ve Eğitim Komisyonunun yüz yüze görüşmesi sonucunda zorbalık belirtilerine rastlanmaz. Aile, A'nın sınıf arkadaşlarıyla yaptığı bağımsız görüşmelerde zorbalığa işaret eden ifadelere ulaşır. Ailenin, üçüncü taraflarca yeni bir soruşturma komitesi talebi Eğitim Kurulu'nca reddedilir. Okul tarafından yapılan soruşturmaya istinaden "zorbalığa dayalı ciddi vaka değildir" sonucu Eğitim Kurulunca onaylanır. Ailenin MEXT'e başvurusu sonucu Eğitim Komisyonu kararını geri çeker.

•• Bakanlık Yorumu: Aile tarafindan sunulan birçok somut kanıta rağmen olay sonrası yürütülen ön sorușturma uygunsuzluklar içerir. Zorbalık şüphesine rağmen, Eğitim Kurulunun "zorbalığa dayalı ciddi vaka değildir” kararı yasaya aykırı hatalı bir karardır.

Vaka 46.Yetersiz ön soruşturma nedeniyle ileride sorun yaşanılan durum

• A, ilkokul ikinci sınıftayken nakil olarak geldiği yeni sınıfında "mikrop" gibi lakaplar takılarak zorbalığa uğrar. İlkokul üçüncü sınıfta Haziran ile Ekim arası tarihlerde okula gitmez (birinci devamsızlık). İlkokul 4. sınıfta; kalemlerinin kırılması, defterlerinin kaybolması, tekmelenme gibi durumlarla zorbalık devam eder. İlkokul beşinci sınıfta diğer 10 çocukla gittiği oyun salonunda yemek, eğlence, ulaşım gibi tüm harcamaların A tarafından karşılanması sağlanır. Okul, yüksek miktardaki para alışverişini fark etse de tam miktarı belirleyemez ve polise bildirimde bulunur. Diğer yandan, para iadesinin okul sorumluluğunda olmadığı gerekçesiyle konuyu ciddi vaka olarak görmez. A, ilkokul beşinci sınıfın Haziran ayından mezuniyet tarihine kadar okula gitmez (ikinci devamsızlık).

•• Üçüncü taraf soruşturma komitesi raporuna göre; Eğitim Kurulu başlangıçta olayı zorbalığa dayalı ciddi vaka olarak değerlendirmemiş, tüm soruşturma yetkisini okula bırakmıştır. A'nın okula gitmeyi reddettiği tarihten bir yıl yedi ay sonra tekrar soruşturma başlatılır.

$\bullet \bullet \bullet$ Bakanlık Yorumu: Yaşam, beden veya maddi varlığa ilişkin ciddi durum şüphesinin oluştuğu durumlarda "ciddi vaka" kararının verilmesi gerekir. Bu vakada ilkokul ögrencilerinin yüksek para alışverişinde bulunduğunun anlaşılması vakanın ciddi durum olarak değerlendirmesinde yeterliydi. 
Vaka 47. Erken ve uygun soruşturma yürütülen, mağdur desteği sağlanan örnek

- İlkokul 5. sınıf kız öğrenci A; sınıf arkadaşı erkek öğrenci B tarafından ayrımcı sözler nedeniyle fiziksel ve ruhsal acı hisseder. Durumu fark eden sınıf öğretmeni, B'nin A'dan özür dilemesini sağlasa da A'nın velisi B'nin özür sonrasında da A'ya yönelik tacizlerine devam ettiğini bildirir. Bunun üzerine müdür ve öğretmen; A, B ve her iki tarafın ebeveynleriyle görüşme yapar; durumun doğruluğunu teyit eder. Tüm taraflara eğitim danışmanlığı sağlanır, ancak A zamanla okula gelmemeye başlar ve sonuç olarak kırk gün devamsızlık yapar.

•• Okul, A'nın devamsızlığını Eğitim Kuruluna “ciddi durum” olarak bildirir. Eğitim Kurulu okula sistematik çalışması, A'nın okula dönüşüne birincil önem vermesi, ilgili kuruluşlardan destek alması talimatını verir. Bunun üzerine müdür, sınıf öğretmeni, öğretmen ve özel destek eğitimi koordineli şekilde aşağıdaki eylemlere başvurur: 1. Öğrenim desteği dâhil olmak üzere A'ya ev ziyareti; 2. A'nın eviyle telefon görüşmesi; 3. B'ye rehberlik; 4. B'nin ebeveynleri ile düzenli görüşme; 5. Okul içindeki ilgili komite ve öğretmenlere durum bildirimi, 6. Rehberlik personelinin geribildirimlerinden yararlanma. Sonuç olarak, okula gitme endişesi ortadan kalkan A okula döner. Ayrıca, B'ye öz benliği artırıcı eğitim danışmanlığı sağlanır.

$\bullet \bullet \bullet$ Bakanlık Yorumu: Erken dönemdeki ev ziyaretleri ile süreklilik gösteren öğrenim desteği ve eğitim danışmanlığı A'nın okula erken dönüşü mümkün kılmıştır. B'ye eğitim danışmanlığı sağlanması sonucu gözlemlenen öz benlikte yükseliş ve pişmanlık belirtileri uygun rehberlik yaklaşımına işaret eder.

\section{Zorbalık Olgusuna İlişsin Literatür Çalışmaları}

$\mathrm{Bu}$ bölümde literatür taraması yolu ile zorbalık olgusunun sahadaki yansımaları değerlendirilecektir. Bu bağlamda öncelikle zorbalık taraflarından "mağdur" ve "fail” profilleri irdelenecektir. Ardından, öğrencilerin zorbalık olgusuna yaklaşımları ele alınacaktır.

\section{Zorbalık Taraflarının Genel Özellikleri}

"Zorbalık" denildiğinde, ilk olarak baskın öğrencinin hedef öğrenciye uygun olmayan davranışta bulunması akıllara gelir. Diğer yandan Japonya'da yapılan birçok araştırma "fail" ve "mağdur" konumlarının sabit olmadığını; öğrencilerin eğitim hayatı boyunca iki farklı pozisyonu da deneyimleyebildiğini ortaya koyar. Dolayısıyla; zorbalık olgusunun taraflarından bahsederken "mağdur", "fail”, ve "her ikisi” şeklinde bir sinıflandırmaya gitmek mümkündür.

"Mağdur" konumundaki öğrenciler üzerine yapılan çalışmalar bu gruptaki öğrencilerin genel olarak keyifsiz, kızgın ve isteksiz olduklarını; depresyon ve kaygı bozukluğu belirtileri sergilediklerini ortaya koyar (Kurokawa, 2010). $\mathrm{Bu}$ deneyimi yaşayan öğrenciler uzun süre travma sonrası stres bozukluğu yaşayabilmekte (Hosawa, 2004), zorbalık sorununu çözümlense de yaşamlarındaki olumsuz izler kısa vadede silinmeyebilmektedir (Banzai, 1995).

Mağdur öğrencilerin durumla baş etme eğilimi, cinsiyete göre farklılık gösterebilir. Honma (2006), erkek öğrencilerin zorbalığa karşı doğrudan harekete geçerken; kız öğrencilerin üçüncü şahıslara danışma ya da yeni ilişki geliştirmeye yatkınlık gösterdiğini ortaya koyar. Hishida \& Ishikawa (2011), zorbalıkla karşılaşan kız öğrencilerin "uzak durma", "hiçbir şey yapmama", "danışma" seçeneklerine öncelik verirken, erkek öğrencilerin "durmalarını söyleme", "yapılanı ödetme" gibi doğrudan eyleme yöneldiği sonucuna ulaşır. Benzer eğilimin izleri, öğrencilere “Zorbalığa uğrayan bir kişiye nasıl yardım edilebilir?” sorusunu yönelten Fukushima (2008)'da da görülür. Çalışma sonucu, erkek öğrencilerin faile yönelik doğrudan eylem içeren ifadeleri, kız öğrencilerin ise mağdura yönelik empati içeren ifadeleri sıklıkla dile getirdiğini ortaya koyar.

Diğer yandan "fail" konumundaki öğrencilerin genel özelliklerine ilişkin "suçluluk duygusunun" yeterince gelişmediği (Ōnishi, Kurokawa, \& Yoshida, 2009); "bağımsızlık" ve "işbirlikçilik" puanlarının düşük "dışlayıcılık" puanının ise yüksek olduğu ifade edilir (Honda, 2012). Honma (2003), bu gruptaki öğrencilerde "kurallara uymaktan kaçınma" ve "saldırganlık" eğiliminin yansıra "empati ve ahlaki farkındalık" düşüklügüne işaret eder. Murase (2013), zorbalık eylemine başvuran çocuklar arasında evlerinde kötü muamele ya da aşırı beklentiye maruz kalan, okulda stres yaşayan; bir yardım sinyali olarak bu davranışlara yönelenlerin azımsanmayacak sayıda olduğunu belirtir.

Fail davranışlarını konu alan çalışmalarda önlem olarak, "prososyal" (Kubota, 2003b; Hishida \& Ishikawa, 2011) ve "işbirlikçî" (Mishima, 2003a) davranış ediniminin güçlendirilmesi; "stresle başa çıkma" (Fukunaga, Murata, \& Chikamori, 2011) yetisinin geliştirilmesi öne çıkar. Tomokiyo (2004), "fail” konumundaki öğrencilerin ileride "mağdur" konumuna düşme kaygısı taşıdığına dikkat çekerek; 1slah etme yerine topyekûn sınıf ortamını iyileştirici önlemlere önem verilmesi gerektiğini belirtilir.

"Mağdur" ve "fail" konumunun sabit olmadığı çok sayıda araştırmada ortaya konulmaktadır. MEXT bünyesinde faaliyet gösteren Ulusal Eğitim Politikaları Enstitüsünün zorbalık takip araştırmasında; ilkokul 4. sınıftan ortaokul 3. sınıfa kadarki altı yıllık sürede şiddet içermeyen zorbalık kapsamında (arkadaşlıkta çıkarma, görmezden gelme, dedikodu) "mağduriyet deneyimi olmayanlar" ile "zorbalık deneyimi olmayanlar"ın benzer şekilde yaklaşı yüzde on oranına sahip olduğu açıklanır (Kokuritsu kyōikuseisaku kenkyushō, 2016). Bu sonuç; öğrencilerin büyük bölümünün her iki konumu da deneyimlediğini ortaya koyar. Itō, (2009) ilk, orta ve lise öğrencisi dokuz bini aşkın katılımcı ile yaptığı çalışmada tüm kademelerde her iki pozisyonu da deneyimleyenlerin azımsanmayacak sayıda olduğunu vurgular. Nakahara \& Akikawa (2006), ilkokul kademesinde her iki deneyime sahip olanların oranını yüzde kırk dört olarak ifade eder. Söz konusu sonuçlar, failin mağdur; mağdurun fail konumuna geçebileceği anlamına gelir. 
Herkesin zorbalığın hedefi olabileceğine dikkat çeken Masuda (2013); bu olasılığı "Rus ruleti" benzetmesi ile ifade etmektedir.

Aynı öğrencinin "mağdur" ve "fail" olarak farklı pozisyonlarda konumlanabilmesi, birbirinin karşıtı gibi görülen bu iki grup arasında gözlemlenen temel benzerlikleri de anlaşılır kılar. Örneğin; Fujihara \& Uğai (2009), "fail”" ve "mağdur" skorları arasında erkeklerde orta derecede, kızlarda yüksek derecede bir korelasyondan söz eder. Itō (2017), "fail" ve "mağdur" grubuna mensup öğrencilerin benzer şekilde "öz benlik" puanlarının düşüklügüne dikkat çeker ${ }^{6}$. Diğer yandan, Matsumoto, Yamamoto, \& Hayami (2009), konuya "varsayımsal yeterlilik" kavramı merkezinde yaklaşır. "Varsayımsal yeterlilik"; "kişinin doğrudan yaşadığı pozitif deneyimlerden bağımsız olarak, başkasının kabiliyetini düşük görme eğilimi sonucu, alışkanlık mahiyetinde meydana gelen yeterlilik duygusu" olarak tanımlanır (Hayami, Kino, \& Takagi, 2004). "Fail” konumundaki öğrencinin mağduru aşağılamayı üstünlük hissi için firsat olarak görebileceğini öne süren Matsumoto, Yamamoto, \& Hayami (2009), çalışma sonucunda fail deneyimi ile mağdur deneyimi arasında pozitif korelasyon gözlemlendiğini; öğrencilerin "varsayımsal yeterlilik" puanı arttıkça "fail", "mağdur" ya da "her iki" konumu deneyimleme sıklıklarının da arttığını belirtir.

\section{Öğrencilerin Genel Zorbalık Algısı}

Japon eğitim sistemindeki zorbalık olgusunu irdeleyebilmek için konunun birincil tarafları olan öğrencilerin ne tür bir yaklaşım sergilediğini anlamak önem arz eder. Bu bağlamda, ilkokul öğrencilerinin zorbalığa bakış açısını irdeleyen Sakai (2010), katılımcıların yüzde doksanının "yapılmaması gerektiği” fikrini benimsediğini belirtir. Diğer yandan aynı çalışmaya göre, katılımcıların yüzde altmışından fazlası "karşı tarafta da sorun olduğu için elden bir şey gelmez" düşüncesini paylaşır.

Kubota (2003a); ilkokulda zorbalık eylemine başvuran öğrencilerin buna sebep olarak ilk sırada "karşı tarafin kötü yönünü"; ikinci sırada "eğlenme, dalga geçmeyi” öne sürdüğünü belirtir. Geçmişte mağdur deneyimi yaşayanlar ise zorbalıkta bulunma nedeni olarak "herkes yaptı̆̆ için" ifadesini daha sık tercih etmektedir. Çalışmada kız öğrencilerin "karşı tarafın kötü yönüne", erkek öğrencilerin ise "eğlenme, dalga geçme" niyetine daha sık atıf yaptı̆̆ vurgulanır. Benzer şekilde ilkokul öğrencilerinin zorbalık eylemine yönelme nedenini irdeleyen Sakai (2009); "karş1 tarafın kibirlenmesi", "misilleme" ve -nedeni açıkça ortaya koymayan- "bir şekilde" (nanto naku) yanıtının sık tercih edildiği sonucuna varır.

İlkokul öğrencilerinin yukarıda belirtilen yaklaşımına ilişkin sonuçlar; öğretmen görüşlerini konu alan az sayıdaki çalışma ile paralellik gösterir. Bu bağlamda, Mishima (2003b)'nın çalışması dikkat çekicidir. 10 yılı aşkın deneyime sahip ilkokul öğretmenleri ile yapılan mülakatlarda "mağdur için üzülse de dı̧̧lanma korkusu ile hareket eden öğrencilerin varlığı"; "şiddet içerikli eylemlerin erkek öğrencilerce, arkadaşlıktan çıkarma ya da görmezden gelme eylemlerinin kız öğrencilerce sık tercih edildiği"; "eğlence amaçlı zorbalık türünde faillerin olayı zorbalık olarak algılamadığı" görüşleri öne çıkar (Mishima, 2003b).

İlkokul ile benzer şekilde ortaokul kademesinde de sorunun kaynağını mağdurla ilişkilendirme eğilimi görülür. Bu yaş grubunda, özellikle "görmezden gelme" ve "arkadaşlıktan çıkarma" gibi zorbalık eylemlerinde bu eğilim daha belirgin hâl alır (Tsukamoto, 2008). Fukunaga, Murata, \& Chikamori (2011), ortaokul öğrencileri ile yaptığı çalışmada, hayali olarak yarattıkları dört ayrı tiplemeye yönelik katılımcıların zorbalıkta bulunma eğilimini araştırır. Araştırma sonucuna göre, katılımcıların yaklaşık yarısı "insan ilişkileri zayıf fakat sürekli takdirname alan" ile "obez" tiplemelerine zorbalık yapabileceğini belirtirken; "yalancı" ve "bencil" tiplemelerinde bu oran yüzde yetmişe çıkar.

$\mathrm{Bu}$ kademedeki öğretmen görüşlerini irdeleyen çalışmalar arasında ortaokul öğretmenlerin zorbalık algısını kavramsallaştırmayı amaçlayan Nakamura \& Hirōka (2004)'nın araştırması öne çıkar. Faktör analizi uygulanan çalışmada, zorbalık kaynağına ilişkin öğretmen algısının "kurallara uymama gibi normatif bilinçte zayıflama"; "kişisel farklılıklara yönelik tolerans eksikliği" ve "mağdur kaynaklı olası sorunlar" faktörlerinden şekillendiği sonucuna ulaşılır. Bunlardan "mağdur kaynaklı olası sorunlar", ilkokul öğrencilerinin dile getirdiği "karşı tarafta da sorun olduğu için elden bir şey gelmez" görüşü ile (Sakai, 2010) benzerlik göstermektedir.

Son olarak lise öğrencilerinin zorbalık algısını irdeleyen araştırmalar incelendiğinde bu çalışmaların ilkokul ve ortaokul kademesini ele alan çalışmalara göre az sayıda olduğu görülmektedir ${ }^{7}$. Fujii (2020), faktör analizi uyguladığı çalışmasında lise kademesindeki öğrencilerin "mağdur" ve "fail" deneyimlerinden yola çıkarak dört zorbalık çeşidine ulaşır. Bunlar; "psikolojik saldırı" ("Başarısızlığıma tüm sınıfça gülündü.", "Görmezden gelindim.”vb.), "sözel saldırı" ("Hakkımda yalan sözler yayıldı.", "Selam versem de karşılık verilmedi." vb.), "maddi saldırı" ("Önem verdiğim eşyalarım çalındı.", "Önem verdiğim eşyalarım saklandı." vb.) ve "fiziksel saldırı"

\footnotetext{
${ }^{6}$ Çalışma sonucunda her iki grupta da öz benlik puanı temel olarak düşük olmakla birlikte; iki grup arasında bir karşılaştırmaya gidildiğinde fail konumundaki öğrencilerin daha düşük skora sahip olduğu görülür.

7 3. Bölümde ifade edileceği üzere, zorbalık vakalarının ilk ve orta kademelerde sık gözlemlenirken lise kademesinde düşüşe geçmesi çalışmaların bu iki kademede yoğunlaşmasına neden olmaktadır. Diğer yandan lise öğrencilerinin zorbalık davranışlarını konu alan literatür çalışmaların çoğunluğu "siber zorbalık" konusunu ele almaktadır. Bu çalışmada "siber zorbalık” kapsam dışı bırakılmıştır.
} 
(“Dövüldüm.”, “Tekmelendim”. vb.) olarak adlandırılmaktadır. Çalışmada; lise kademesindeki mağdurların en sık deneyimledikleri zorbalık türünün "maddi saldırı" olduğu belirtilir.

İtō (2017); lise kademesinde "sınıf arkadaşı ile alay etme" eylemine diğer kademelerdeki kadar negatif anlam yüklenmediği sonucuna ulaşır. İki bini aşkın lise öğrencisinin katılımı ile gerçekleştirilen çalışmada "alay etme" eylemine ilişkin "kötü olarak düşünmüyorum" yanıtını verenlerin oranı yüzde 35 (aynı oran ilkokulda yüzde 5.4; ortaokulda yüzde 14.9); "eğlenceli olduğunu düşünüyorum" yanıtını verenlerin oranı yüzde 41.4 (aynı oran ilkokulda yüzde 8.8; ortaokulda yüzde 25.3) olarak ifade edilir.

\section{Zorbalık Olgusuna İlişkin Resmî Vaka Sayıları}

$\mathrm{Bu}$ bölümde, Japon eğitim sisteminde görülen zorbalık sorunu nicel ve nitel bağlamda somutlaştırılacaktır. Bu bağlamda, MEXT (2019a) tarafından kamuoyuna sunulan 2018 Yılı Öğrencilerin Problemli Davranışları ve Öğrenci Rehberliğinde Yaşanan Sorunlara İlişkin Araştırma Sonuç Özeti’nden yararlanılacaktır. Bu bölümde kullanılan veri setleri, doğrudan söz konusu resmî sonuç raporu verilerini yansıtmaktadır.

\section{Toplam Vaka Sayısı ve Kademelere Göre Dağılımı}

2006-2018 yılları arasında kayıtlara geçen toplam vaka sayısı ve kademelere göre dă̆1lımı Şekil 1'de ifade edilmektedir (MEXT, 2019a). Buna göre, 2018 yılı vaka sayıs1; ilkokullarda 425,844 (bir önceki yıl 317,121), ortaokullarda 97,704 (bir önceki yıl 80,424), liselerde 17,709 (bir önceki yıl 14,789) ve özel destek okullarında 2676 (bir önceki yı1 2, 044) olarak kayıtlara geçmiştir. 2018 verilerine göre toplam vaka sayısı bir önceki yıla göre yüzde 31 artış gösterirken (2018: 543,933; 2017: 417,378); bu artış ilkokulda yüzde 34, ortaokulda yüzde 21, lisede yüzde 19 değerindedir. Diğer yandan, bir önceki beş yıl ile karşılaştırıldığında özellikle ilkokul kademesindeki vaka sayısında büyük artış göze çarpmaktadır (2013: 118,748; 2018: 425,844).

\section{Tanımlanmış Toplam Vaka Sayısı ve Kademelere Göre Dağılım (2006-2018)}

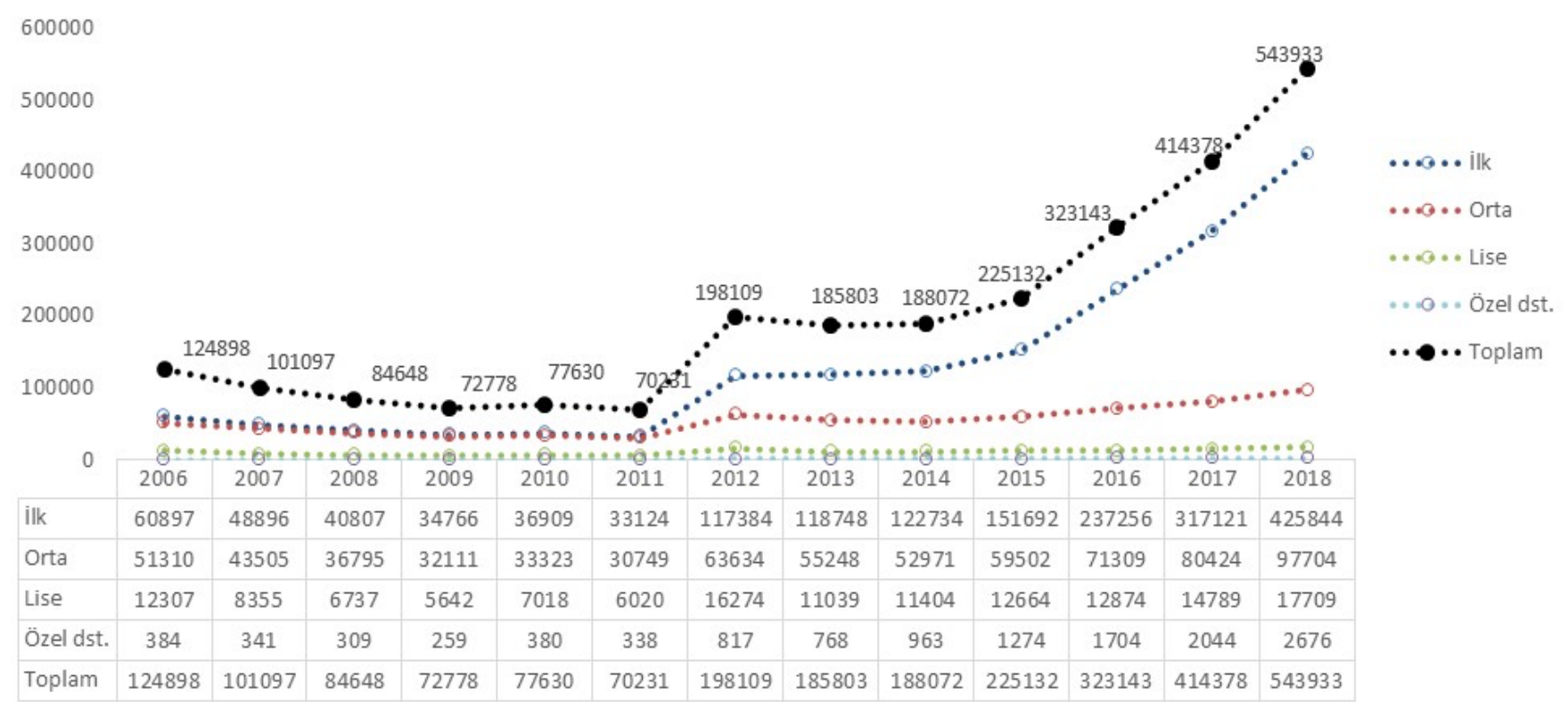

Şekil 1. Tanımlanmış Toplam Vaka Sayısı ve Kademelere Göre Dağılımı (2006-2018)

\section{Vaka Sayısının Sınıflara Göre Dağılımı}

2016-2018 yılları arasındaki tanımlanmış vaka sayısının sınıflara göre dağılımı Şekil 2 'deki gibidir ${ }^{8}$ (MEXT, 2019a). Şekil 2'den anlaşılacağı üzere, 2016-2018 yılları arasında özellikle ilkokul kademesindeki vaka sayısında önemli artış söz konusudur. Diğer yandan, kademe bazında değerlendirildiğinde, kademe ilerledikçe vaka sayısında gerileme eğilimi görülür. 2018 verilerine göre; ilkokul 1. sinıflarda vaka sayısı 76,893 iken ortaokul 1. sinıfta bu sayı 50, 258'e, lise 1. sınıfta ise 9724 'e geriler. Lise 4. sinıflarda görülen toplam vaka sayısı yalnızca 45’tir.

\footnotetext{
${ }^{8}$ Özel destek okullarında görülen vaka sayısı ilgili sınıflara dağıtılmıştır.
} 


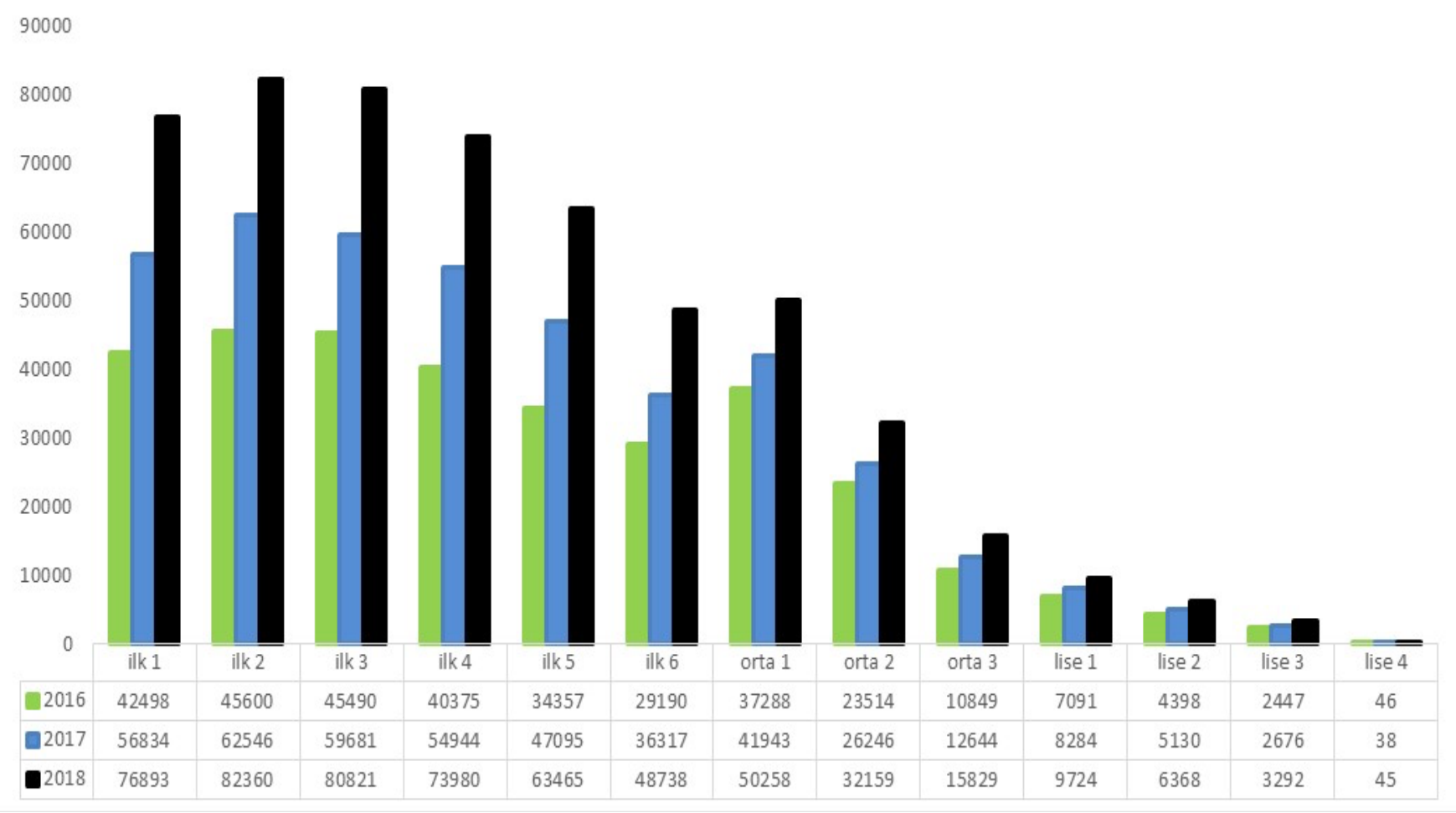

Şekil 2. Tanımlanmış Zorbalık Vaka Sayısının Sınıflara Göre Dağılımı (2016-2018)

\section{Vaka İçerikleri ve Kademelere Göre Dağılımı}

Şekil 3, kademelere göre en sık görülen zorbalık durumlarını ifade etmektedir (MEXT, 2019a). Buna göre, tüm kademelerde en sık görülen zorbalık durumu "Soğuk davranış, alay, küfür, tehdit, azar ya da söylenilen kötü söz," olarak karşımıza çıkar (ilkokul yüzde 62, ortaokul yüzde 66,4, lise yüzde 61,4). Bu maddeyi ilk ve ortaokullarda "Hafif çarpma, oyun adı altında dövülme ya da tekmelenme," (ilkokul yüzde 23,5, ortaokul yüzde 11,4); liselerde ise "Bilgisayar veya cep telefonunda iftira ya da nahoş durumlarla karşılaşma" (yüzde 19,1) takip eder. Üçüncü sırada tüm kademelerde "Arkadaşlıktan dışlanma, grup tarafından görmezden gelinme," yer alır (ilkokul yüzde 13,9, ortaokul yüzde 12.5.4, lise yüzde 15,6).

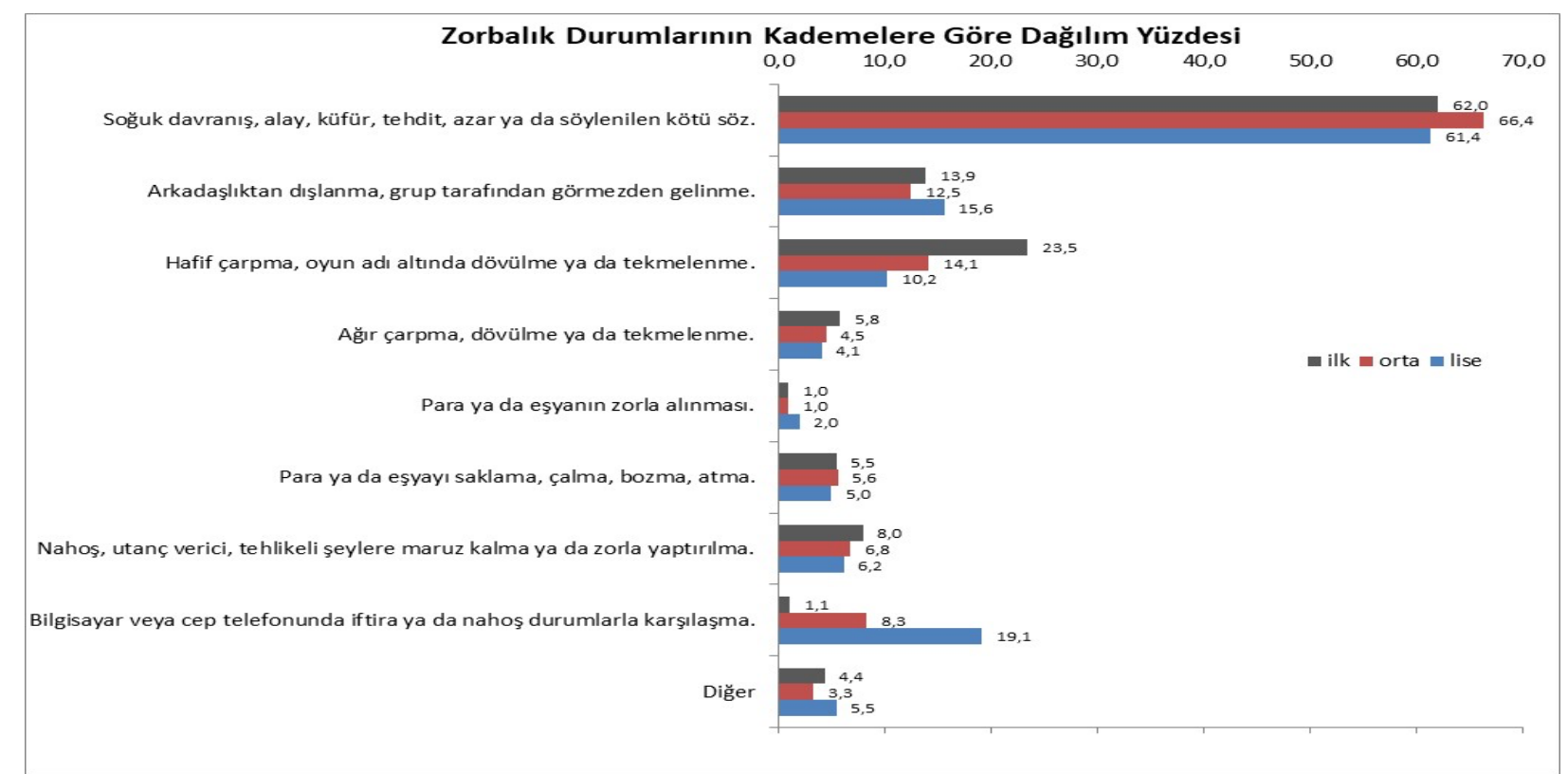

Şekil 3. Zorbalık Durumlarının Kademelere Göre Dăğlım Yüzdesi 


\section{Ciddi Durum Vaka Sayıları}

MEXT (2019a) verilerinde, zorbalık eyleminin ağır sonuçlara yol açtı̆̆ "ciddi durum" vakalarına da yer verilmektedir. Zorbalık Önleme Tedbirleri Teşvik Yasası bu tür ciddi durumları; "zorbalık sonucu, okula kayıtlı bir çocuğun yaşamına, bedenine veya malına ciddi zararlar oluştuğu şüphesinin kabul edildiği durumlar," (Madde 28, 1.F1kra, 1.Bent) ile "zorbalık nedeniyle okula kayıtlı bir çocuğun önemli bir süre okula gitmeyi reddetme zorunda kaldığ 1 durumlar," (28. Madde, 1. Fıkra, 2.Bent) olarak iki sınıfta değerlendirmektedir. Yasanın yürürlüğe girdiği 2013 yılından 2018' e kadarki altı yıllık dönemde, kayıtlara geçen "ciddi durum" vaka sayıs1 Tablo 4'teki gibidir" (MEXT, 2019a). Buna göre, 2013 yılında 179 olan toplam vaka sayısı 2018 yılında 602'ye ulaşmakta; 2018 yılındaki vaka sayısı bir önceki yıla (474) kıyasla yüzde 27’lik bir artış göstermektedir ${ }^{10}$.

Tablo 4. Ciddi Durum Vaka Sayıs1 (2013-1018)

\begin{tabular}{|c|c|c|c|c|c|c|c|}
\hline & Y1l & 2013 & 2014 & 2015 & 2016 & 2017 & 2018 \\
\hline & Ciddi Durum Toplam Vaka Sayısı & 179 & 449 & 314 & 396 & 474 & 602 \\
\hline 1 & Yaşam, beden veya maddi varlığa ilişkin ciddi vaka & 75 & 92 & 130 & 161 & 191 & 270 \\
\hline 2 & Okula gitme reddine ilişkin ciddi durum vaka & 122 & 385 & 219 & 281 & 332 & 420 \\
\hline
\end{tabular}

\section{Değerlendirme}

Bu çalışmada, Japon eğitim sisteminde uzun yıllar çözüm bekleyen bir sorun olarak varlığını sürdüren "zorbalık" (ijime) olgusu irdelenmiştir. Bu amaçla, zorbalık tanımının zaman içindeki değişimi incelenmiş; zorbalık olgusunun sahadaki yansımaları güncel resmî veriler ışığında ele alınmıştır. Çalışma sonucunda öne çıkan noktalar (1) "resmî bakış açısı ve sahadaki yansıması" (2) "zorbalık nedeni ve çözüm arayışı” başlıkları altında değerlendirilebilir.

Öncelikle, resmî bakış açısı ve sahadaki yansımasına ilişkin, günümüzde de geçerliliğini koruyan zorbalık tanımlaması belirleyici bir rol oynar. 2013 yılında yürürlüğe giren Zorbalık Önleme Tedbirleri Teşvik Yasası ile zorbalık; "Bir öğrenciye yönelik olarak; söz konusu öğrenci ile aynı okula kayttl olma gibi belirli bir insan ilişkisi dâhilinde diğer bir öğrencinin gerçekleştirdiği psikolojik ya da fiziksel etki yaratan eylemler sonucu (internet aracıliğ ile olanları da kapsar), hedef konumundaki ögrencinin ruhsal ve fiziksel acı çekmesi" olarak tanımlanmaktadır. Bu tanımlamada; daha önceki tanımlamalarda kullanılan "süreklilik", "tek taraflılık", "derin" gibi ifadelere yer verilmez. 1994 yılı sonrası "mağdur odaklı" bir yaklaşıma geçilmesi; geniş çerçeveli bir bakış açısı ile mümkün olduğunca fazla erken tanı ve müdahale stratejisinin izlerini taşır (Takashi, 2017). İnsan haklarını önemseyen bu bakış açısı "yüksek vaka sayısı" olarak karşılık bulurken; sahada yaşanacak algı farklılığına da zemin hazırlayabilmektedir.

"Mağdur odaklı" bir yaklaşım, beraberinde "öznel algı farklılığı" sorununu getirebilmektedir. Bu bağlamda, bir öğrenci ya da velinin zorbalık olarak nitelendirdiği bir davranış, diğer öğrenci ya da veli tarafından "şakalaşma" olarak değer görebilir (Fujii, 2020). Benzer şekilde mağdurun zorbalık olarak tanımladığı bir eylemi öğretmenin sorun olarak değerlendirmediği durumlar da söz konusu olabilmektedir (Morita, 2010).

Monbukagakushō (2019c), öğretmenlere yönelik yazılı açıklamasında sahadan yükselen bu sesleri anlaş1lır bulduğunu; fakat yasadaki zorbalık tanımlamasına uyulması gerektiğini belirtir. Yüksek vaka sayısının ilgili personelin özenli ve dikkatli davranışına işaret ettiği vurgulanan açıklamada; zorbalık kaynaklı intihar olaylarının büyük bölümünün önemsiz addedilen olaylarla başladığı hatırlatılarak -bir kerelik bir eylem olsa da- ögretmenlerden yasaya riayet etmeleri istenir. MEXT'in yasadaki tanımlamayı temel alarak sahada ortak bir alg1 yaratma gayreti, önceki rapor ve genelgeleri ile de tutarlılık gösterir (ör. Monbukagakushō, 2014b; 2016; 2017a-b; 2018).

Zorbalık nedeni ve çözüm arayışını konu alan çok sayıdaki çalışmada "prososyal ve işbirlikçilik davranış", "stresle başa çıkma yetisi”, "öfke kontrolü”, "öz benlik" gibi kavramlar öne çıkmaktadır. Okul danışmanlık sistemi dâhilinde rehberlik hizmeti veren uzmanlar şüphesiz ki sahada bu yaklaşımları göz önünde bulundurmaktadır. MEXT'in (2018) Ciddi Durum'lara ilişkin olumlu örnek olarak sunduğu vakada (Tablo 3; vaka 47); faile yönelik öz benliği yükseltici rehberlikte bulunulması olumlu olarak değerlendirilmektedir. Diğer yandan 1980'li yıllardan itibaren Japonya gündeminde yer alan zorbalık sorununun aradan geçen yaklaşık kırk yıla rağmen hâlâ çözümlenememiş olması durumun ne kadar köklü olduğuna işaret eder. Sorunun çözümündeki en büyük güçlük; Japon toplumunun karakteristik özelliği arasında gösterilen "kolektivist yaklaşım" ile ilintilidir. Lebra (2013, ss. 5052) kolektivizmi; "Bireyin kendi amacını ait olduğu grubun ortak amacıyla özdeşleştirmesi" olarak tanımlar. Japonya' da eve misafir davet edildiğinde komşu ve akrabaların gönüllü olarak hazırlıklara yardım etmesi; yurt içi ya da yurt dışı seyahatlerde grup turlarının tercih edilmesi; birlikteliğe duyulan kültürel cazibe nedeniyle en küçük olayda kolayca sabishī (yalnız) hissiyatının ortaya çıkması Japonların güçlü kolektivist eğilimine işaret eder.

\footnotetext{
${ }^{9}$ Olayın içeriğine göre aynı vakanın 1. ve 2. grup dâhilinde ayrı ayrı sınıflandırıldığı durumlar söz konusu olduğundan, tekil vaka olarak hesaplanan toplam veri sayısı 1 . ve 2 . grup vaka sayısı toplamından daha düşüktür.

${ }^{10}$ Söz konusu 602 vakanın eğitim kademelerine göre dağılımına da yer verilen raporda, bu dağılım ilkokulda 188, ortaokulda 288 , lise de 122 ve özel eğitim destek okullarında 4 olarak ifade edilir (Monbukagakushō, 2019a).
} 
Miyahara (1983), zorbalık tartışmalarının başladığı görece erken dönemde sorunun özüne ilişsin "kolektivizm" olgusuna dikkat çekerek; "Modern Japonya'da zorbalık; homojen kolektif atmosfere uyum sağlamayanlara karşı ayrımcılık, nefret, görmezden gelme ifadesi olduğu gibi, kişinin bu homojen gruptan tek başına çıkarllma korkusunun da bir ifadesidir," tespitinde bulunur. Öğrencilerin zorbalık yaklaşımında öne çıkan "karşı tarafın sorunlu yönüne işaret etme" ve "“dışlanma korkusu ile eyleme katılma” gibi sahadan yansıyan bulgular; Miyahara (1983)'nın tespitinin günümüzde de geçerli olduğuna işaret eder. Bu durum "kişisel farklılığa tolerans" gibi (Nakamura \& Hirōka, 2004) sorunun özüne yönelik atılacak olası adımlarda, "kolektivist" eğilimi göz önünde bulunduran planlı ve kararlı politikalara ihtiyaç duyulacağını akıllara getirir.

Bu çalışmada Japon eğitim sisteminde görülen 'zorbalık' olgusu irdelenmiş; resmî veriler ve alan çalışmaları 1şığında bir çerçeve çizilmeye gayret edilmiştir. Bu bağlamda; mümkün olduğunca fazla vakayı kayıt altına almayı hedefleyen resmî politika ile bu durumun sahadaki yansımaları öne çıkarılmış; zorbalık nedeni ve çözüm arayışları değerlendirilmiştir. İleride; bu çalışmada yeterince irdelenmeyen okul danışmanlık sistemi (sukūru kaunserā) ile çalışmada kapsam dışı bırakılan "siber zorbalık" konularının ele alınması gerekir.

\section{Araştırmacıların Katkı Oranı}

Yazar çalışmanın tamamını gerçekleştirmiştir.

\section{Destek ve Teşekkür}

Yazar çalışma için herhangi bir finansal destek almamıştır.

\section{Çıkar Çatışması}

Yazar çalışmada herhangi bir çıkar çatışmasının bulunmadığını beyan etmiştir. 


\section{Kaynakça / References}

Banzai, T. (1995). Ijime ga higaisha ni oyobosu chōkitekina eikyō oyobi higaisha no jiko ninchi to hokano higaisha ninchi no sa [Zorbalığın mağdur üzerindeki uzun süreli etkisi ve mağdurun benlik algısı ile diğer mağdur algısı arasındaki fark]. Shakai shinrigaku kenkyū, 11(2), 105-115.

Baydilek-Başaran, N. (2015). Japonya’da okul öncesi eğitim. Adnan Menderes Üniversitesi Eğitim Bilimleri Dergisi, 6(1), 1-13.

Ekinci, A. (2010). Japon Eğitim Sisteminden Türk Eğitim Sistemine iyi örnekler. Milli Eğitim Dergisi, 40(188), 32-49.

Fujihara, M., \& Ugai, A. (2009). Shitashī yūjinkan ni okeru "Ijime" to seisa shōgakusei no bāi [Yakın arkadaşlıklarda görülen "zorbalık" ve cinsiyet farklılıkları: İlkokul kapsamında]. Bunkyōdaigaku kyōikugakubu kiyō, 43, 71-79.

Fujii, Y. (2020). Kōkōsei no "Ijime ninchi” ni kansuru jisshōteki kenkyū [Lise öğrencilerinin "zorbalık algısı" üzerine ampirik bir araştırma]. İwatedaigaku kyōikugakubu fuzokukyōiku jissensōgō sentā kenkyūkiyō, 19, 77-88.

Fukunaga, N., Murata, M., \& Chikamori, K. (2011). Chūgakusei no sutoresu taishō kōdō to ijime ni kansuru kenkyū [Ortaokul öğrencilerinin stresle başa çıkma davranışları ile zorbalığa ilişkin çalışma]. Tōkai gakkō hoken kenkyū, 35(1), 33-42.

Fukushima, H. (2008). Chūgakusei no jikokōryokukan to moetsukishōkōgun, ijime, jisatsu mondai ni taisuru ninshiki to no kanren [Ortaokul öğrencilerinin öz yeterlikleri ile tükenmişlik sendromu, zorbalık ve intihar sorunlarına ilişkin farkındalıkları arasındaki ilişki]. Kokoro no kenkyū, 23(1), 56-64.

Güçlüol, K. (1984). Japon eğitimi üzerine notlar. Ĕgitim ve Bilim, 4(8), 4-12.

Güvenç, B. (2002). Japon Kültürü (4. baskı). İstanbul: Türkiye İş Bankası Kültür Yayınları.

Hayami, T., Kino, K., \& Takagi, K. (2004). Kasōteki yūnōkan no kōseigainen datōsei no kentō [Varsayılan yeterlik ölçeğinin yapısal geçerliği incelemesi]. Nagoyadaigakudaigakuin kyōikuhattatsukagaku kenkyūkakiyō, 51, 1-8.

Hishida, K., \& Ishikawa, T. (2011). Ijime no eikyō to rejiriensh̄̄, sōsharu sapōto, raifu sukiru to no kanren [Zorbalığın etkileri ile dayanıklılık, sosyal destek, yaşam becerisi arasındaki ilişki]. Japanese Journal of School Health, 53(2), 107-126.

Honda, M. (2012). Bunkateki jikokan, haitasei, jisonshin to ijime no kanren -Shōgakusei wo taishōni [Kültürel benlik, dışlayıcılık, öz benlik ile zorbalık arasındaki ilişki: İlkokul öğrencileri üzerine]. Miyagigakuinjoshidaigaku daigakuin jinbun gakkaishi, 13, 83-96.

Honma, T. (2003). Chūgakusei ni okeru ijime no teishi ni kanren suru yōin to ijime kagaisha e no taiō [Ortaokul öğrencileri kapsamında zorbalığın sonbulması ile ilişkili etmenler ve zorbalara yönelik müdahale]. Japanese Journal of Educatıonal Psychology, 51(4), 390-400.

Honma, T. (2006). Ijime higai chūgakusei ni yoru ijime e no taisho to kaiketsu -Ijime higaisha e no shien ni mukete [Ortaokul öğrencilerince zorbalıkla başa çıkma ve çözüm: Zorbalık mağdurlarına desteğe yönelik]. Kyoto University of Education Bulletin, 108, 143-150.

Hosawa, H. (2004). Ijime wo keiki tosuru gaishōgo sutoresu shōgai no rikidōteki shinriryōhō [Zorbalığın tetiklediği travma sonrası stres bozukluğuna ilişkin dinamik psikodinamik terapi yöntemi]. Shinririnshōgaku kenkyū, 22(3), $240-249$.

Ijime bōshitaisaku gyokikai (2016). Ijime bōshitaisaku suishinhō no shikōjōkyō ni kansuru giron no torimatome [Zorbalık önleme tedbirleri teşvik yasasının uygulama durumuna ilişkin tartışma özeti]. Erişim: https://www.mext.go.jp/b_menu/shingi/ chousa/shotou/124/index.htm

Itō, M. (2017). Ijimeru, ijimerareru keiken no haikei yōin ni kansuru kisōteki kenkyū -Jisonkanjō ni chakumoku shite [Zorbalıkta bulunma, bulunulma deneyimlerinin arkasında yatan faktörlere ilişkin temel bir araştırma: Benik saygısı 1şığında]. Japanese Journal of Educational Psychology, 65, 26-36.

Itō, Ş. (1996). Kokoro no mondai toshite no ijime mondai [Ruhsal bir sorun olarak zorbalık sorunu]. Kyōikushakaigakukenkyū, 59, 21-37.

Kıral, B., \& Kıral, E. (2009). Japonya ilköğretim sistemi ve Türkiye ilköğretim sisteminin karşılaştırılması. Dicle Üniversitesi Ziya Gökalp Ĕ̈itim Fakültesi Dergisi, 12, 53-65. 
Kobayashi, E., \& Miwa, S. (2013). Ijime kenkyū no dōkō -Teigi to ijime taisaku no shiten wo megutte [Zorbalıkla ilgili araştırmalara ilişkin yorumlar: Tanım vezorbalık önlemleri üzerine]. Kyōikushinrigaku kenkyū, 50(4), 487-499.

Kokuritsu kyōikuseisaku kenkyushō. (2016). Ijime tsuiseki chōsa 2013-2015 [Zorbalık Takip Araştırması 2013-2015]. Erişim: https://www.nier.go.jp/shido/centerhp/2806sien/ tsuiseki2013-2015 _ 3.pdf

Kubota, M. (2003a). Ijime o seitōka suru kodomotachi -Ijime kōi no seitōka ni eikyō wo oyobosu yōin no kentō [Zorbalığ1 meşrulaştıran çocuklar: Zorbalık davranışının meşrulaştırılmasını etkileyen faktörlerin incelenmesi]. Kodomoshakaikenkyū, 9, 29-41.

Kubota, M. (2003b). Gakkyū ni okeru ijime seiki no eikyōyōin no kentō -Gakkyū shūdan tokusei to kyōshi ni yoru ijime yobōsaku ni chakumoku shite [Sınıfta zorbalık oluşumunu etkileyen faktörlerin incelenmesi: Sınıf grup özelliği ve öğretmene bağlı zorbalık tedbirleri odakl1]. Nihon tokubetsukatsudō gakkaikiyō, 11, 95-104.

Kurokawa, M. (2010). Ijime higai to sutoresu hannō, nakama kankei, gakkō tekiōkan tono kanren-Denshi ijime higai mo fukumeta kentō [Zorbalık mağduriyeti ile stres tepkisi, akran ilişkilsi, okul tepisi arasındaki ilişki: Siber zorbalığı da göz önünde bulunduran bir değerlendirme]. Japanese Journal of Counseling Science, 43, 171-181.

Lebra, T. (2013). Japonlar ve davranış biçimleri. (Çev. O. Baykara) İstanbul: Boğaziçi Üniversitesi Yayın Evi.

Liman, F. (2012). Japon Eğitim Sistemi. Ö. Demirel (Ed.), Gelecek için eğitim: Farklı ülkelerde program geliştirme çalışmaları içinde (ss. 113-127). Ankara: Pegem.

Masuda, K. (2013). Ijime mondai e no kōzōteki kainyū [Zorbalık sorununa yönelik yapısal müdahale]. Rinshōshinrigaku, 13, 669674.

Matsumoto, M., Yamamoto, M., \& Hayami, T. (2009). Kōkōsei ni okeru kasōteki yūnōkan to ijime to no kanren [Lise öğrencilerinde görülem varsayılan yeterlilik duygusu ile zorbalık ilişkisi]. Japanese Journal of Educational Psychology, $57(4), 432-441$.

Mishima, K. (2003a). Shitashī yūjinkan ni mirareru shōgakusei no "ijime” ni kansuru kenkyū [Yakın arkadaşlar arasında görülen ilkokul öğrencilerindeki "zorbalığa" ilişkin bir çalışma]. Shakai shinrigaku kenkyū, 19, 41-50.

Mishima, K. (2003b). Shōgakkōkyōshi ga imēji suru danshi, joshi jidō no "ijime" [ìlkokul öğretmenlerinin zihinlerinde canlanan erkek öğrenci ve kız öğrenci “zorbalığı”]. Nagoyadaigakudaigakuin kyōiku hattatsukagakukenkyūkakiyō, 50, $123-132$.

Miyahara, H. (1983). Ijime no kōzō to jissen no kadai [Zorbalığın yapısı ve uygulamadaki zorluklar]. Seikatsushidō, $319,5-8$.

Monbukagakushō. (2012). Hanzaikōi toshite toriatsukawarerubeki to mitomerareru ijime jian ni kansuru keisatsu e no sōdan tsūhō ni tsuite [Suç teşkil eden fiil olarak değerlendirilmesi gereken zorbalık vakalarına ilişkin polis ile istişare ve bildirimde bulunma hakkında]. Erişim: https://www.mext.go.jp/a_menu/shotou/seitoshidou/1327861.htm

Monbukagakushō. (2014a.). Heisei 26 nendo 4 gatsu 11niçi 'Ijime no sain hakken shīto' no haifu ni tsuite [11 Nisan 2014 Zorbalık işaretini fark etmede kontrol çizelgesi]. Erişim: https://www. mext.go.jp/a_menu/shotou/seitoshidou/1400260.htm

Monbukagakushō. (2014b.). Ijime no mondaini taisuru torikumi jireishū [Zorbalıkla mücadelede toplu vaka örnekleri]. Erişim: https://www.mext.go.jp/component/a_menu/education/detail/_ics Files/afieldfile /2018/05/30/1405646_001.pdf

Monbukagakushō. (2017a). Ijime no jūdai jitai no chōsa ni kansuru gaidorain [Ciddi Zorbalık Durumlarının Soruşturulmasına İlişkin Kılavuz Illkeleri]. Erişim: https://www.mext.go. jp/component/a_menu/education/detail/_icsFiles/afieldfile /2019/06/26/1400030_009.pdf

Monbukagakushō. (2017b). Ijime no bōshitō no tame no kihontekina hōshin [Zorbalık Önlenmesine İlişkin Temel İlkeler]. Erişim: https://www.mext.go.jp/component/a_menu/education/detail/__icsFiles/afieldfile/2019/06/26/1400030_007.pdf

Monbukagakushō. (2018). Ijime taisaku ni kakaru jireishū [Zorbalı̆̆a karşı önlemlere ilişsin toplu vaka örnekleri]. Erişim: https://www.mext.go.jp/a_menu/shotou/seitoshidou/_ics Files/afieldfile/2018/09/25/1409466_001_1.pdf

Monbukagakushō. (2019a). Heisei 30 nendo jidō seito no mondaikōdō futokōtō seito shidōjō no shokadai ni kansuru chōsa kekka no gaiyō [2018 yılı ögrencilerin problemli davranışları ve öğrenci rehberliğinde yaşanan sorunlara ilişkin araştırma sonuç özeti]. Erişim: https://www.mext.go.jp/content/20191217_mxt_syoto02-000003300_8.pdf 
Monbukagakushō. (2019b). Ijime no teigi no hensen [Zorbalık tanımındaki değişimler]. Erişim: https://www.mext.go.jp/ component/a_menu/education/detail/ icsFiles/afieldfile/2019/06/26/1400030_003.pdf

Monbukagakushō. (2019c). Ijime no ninchi ni tsuite: Senseigata hitorihitori ga mōichidō kakunin shite kudasai [Zorbalık algılayışı hakkında: Her bir ögretmenimiz, bir kere daha teyit ediniz lütfen]. Erişim: https://www.mext.go.jp/component/ a_menu/education/detail/_ ics Files/afield file/2019/06/26/1400030_005.pdf

Morita, Y. (2010). Ijime to wa nanika: Kyōshitsu no mondai, shakai no mondai [Zorbalık nedir? Sinıf sorunu mu, toplum sorunu mu?]. Tokyo: Chūkōshinsho.

Murase, K. (Ed.). (20013). Gakkō ga motomeru sukūru kaunserā: Asesumento to konsarutēshon wo chūshin ni [Okulun arzuladı̆̆ okul danışmanlı̆̆l: Değerlendirme ve konsültasyon odaklı]. Tokyo: Tomishobo.

Nakahara, C., \& Akikawa, M. (2006). "Mondai no gaizaika" wo mochīta ijime bōshi puroguramu no kokoromi -Shōgakkō teigakunen ni okeru jugyō wo tōshite ["Sorunların dışsallaştırılması" yolu ile zorbalıkla mücadele programı girişimi: İlkokul alt sınıf derslerinden yararlanarak]. Tōkyōgakugeidaigakukiyō, 57, 71-81.

Nakamura, A., \& Hirōka, Ş. (2004). Ijime no taisho to yutakana ningenkankei wo hagukumu kyōiku shien no arikatani tsuite [Zorbalıkla mücadele ve zengin insan ilişkileri geliştirmede arzulanan eğitim desteği]. Miedaigaku kyōikujissensōgōsentā kiyō, 24, 175-184.

Nakano, Ş. (2018). Gakkō ni okeru ijime mondai no rikai to taīo ni kansuru kenkyū -Shisutemuzu apurōchi no shiten kara [Okullardaki zorbalık sorununu anlama ve mücadeleye ilişkin bir çalışma: Sistem yaklaşımı bakış açısıyla] (Yayımlanmamış doktora tezi). Bunkyō Üniversitesi, Japonya.

Ōnishi, A., Kurokawa, M., \& Yoshida, T. (2009). Jidō seito no kyōshi ninchi ga ijime no kagai keikō ni oyobosu eikyō [Öğrencilerin öğretmen algısının zorbalık istismara etkisi]. Japanese Journal of Educational Psychology, 57(4), 324-335.

Ōtsuka, Y. (2012). Wagakuni ni okeru sukūru kaunseringu [Ülkemizdeki okul danışmanlığı]. In Ş. Murayama, \& T. Takiguçi (Eds.), Genba de yakudatsu sukūru kaunseringu no jissai [Sahada faydalı okul danışmanlığı uygulaması] (pp. 35-46). Osaka: Sōgenşha.

Özşen, T. (2020). Modern Japon Eğitim Sisteminin tarihi temelleri üzerine değerlendirme: Meiji'den Shôwa'ya $1868-1950$ arası döneme bakış. Eğitimde Kuram ve Uygulama, 16(1), 36-52.

Sakai, R. (2009). Shōgakkō ni okeru ijime (3) [İlkokulda görülen zorbalık (3)]. Shinshin kagakubukiyō, 5, 31-39.

Sakai, R. (2010). Shōgakkō ni okeru ijime (4) [İlkokulda görülen zorbalık (4)]. Shinshinkagaku, 2(1), 95-103.

Sōmushō gyōseihiyōkakyoku. (2018). Ijime bōshi taisaku no suishin ni kansuru chōsa kekka hōkoku [Zorbalık önleme tedbirlerini teşvike ilişkin araştırma sonuç raporu]. Erişim: https:// www.soumu.go.jp/main_content/000538672.pdf

Sugihara, S. (2013). Kōritsu gakkō sukūru kaunserā katsuyō jigyō no rekishi to hensen -Koyō keitai to kinmu keitai [Devlet okullarının okul danışmanlığından yararlanma tarihçesi ve değişimi: İstihdam ve çalışma şekli]. In K. Murase (Ed.), Gakkō ga motomeru sukūru kaunserā: Asesumento to konsarutēshon wo chūshin ni [Okul tarafindan arzulanır okul danişmanlı̆̆l: Değerlendirme ve konsültasyon odakll] (pp. 19-30). Tokyo: Tomishobo.

Shimoda, Y. (2014). Nihon no shōchūgakusei wo taishōtoshita ijime ni kansuru shinrigakutekikenkyū no dōkō [Japonya'da ilkokul ve ortaokul öğrencileri üzerine zorbalık olgusunu ele alan psikoloji araştırmalarında temayül]. Ningenhattatsukagaku kenkyūjissen sōgōsentākiyō, 8, 23-37.

Suzuki, K. (1995). Gakkō ni okeru ijime [Okullarda zorbalık]. The Annual Report of Educational Psychology in Japan, 34, 132142.

Takanori, S. (1999). Ijime mondai handobukku-Bunseki,shiryō,nenpyō [Zorbalık Sorunu El Kitabl: Analiz, döküman, kronolojik stralama]. Tokyo: Tsugeshoboshinsha.

Takashi, K. (2017). Ijime no teigi no rikai to motomerareru kyōiku jissen [Zorbalık tanımı anlayışı ve beklenilen eğitim uygulamaları]. Narakyōikudaigaku kyōshokudaigakuinkenkyūkiyō , 9, 109-114. 
Tekışık, H. H. (2006). Japonya'da okulu öğrenciler temizliyor. Çağdaş Eğitim Dergisi, 31, 322. Ankara: Evren Yayıncılık ve Basım San.Tic.Aş

Toksöz, L. (2020). Japonya imajını oluşturan faktörler üzerine bir inceleme: Namık Kemal Üniversitesi örneği üzerine. 7. Uluslararası Bilimsel Araştırmalar Kongresi Bildiri Tam Metin Kitabı içinde (ss. 255-268). Ankara: Asos Yayınları.

Tomokiyo, Y. (2004). Ijime kagaisha ni tsuite -Kokunai no senkōkenkyū kara [Zorbalık failleri hakkında: Yurtiçi alan çalışmalarından yola çıkarak]. Fukuokakyōikudaigaku shinrikyōiku sōdankenkyū, 8, 61-68.

Tsukamoto, T. (2008). Chugakkō 1 kurasu e no ijime yobō no jissen to sono kōka no kentō [Ortaokul 1. sınıfa yönelik zorbalığı önleme uygulaması ve etkisinin incelenmesi]. Hirosakidaigaku daigakuin kyōikugakukenkyūka shinririnshō sōdanshitsukiyō, 5, 17-30. 